\title{
The Acceptance of Social Networking as a Learning Tools at University of Bahrain
}

\author{
Jaflah H. Al-Ammary, Amna K. Al-Sherooqi, and Hajer K. Al-Sherooqi
}

\begin{abstract}
Social networks (SNs) are growing rapidly as leading technologies for education and learning platform. They have the potential to create new contents and opportunities that increase student's motivation for learning. However,to have an effective implementation and adoption for such technologies,there is a need to identify factors influence the students' acceptance of such technologies as new learning tools. By relying on the Technology Acceptance Model - TAM model which focuses on perceived usefulness and perceive ease of use as well as behavior intention toward using new technology was used to examine the student's behavior intention toward using SNs as learning tools at University of Bahrain. A quantitative research approach was conducted using survey method.Data were collected from a sample of undergraduate students from Information Systems at the University of Bahrain. PLS was conducted to test the predictive power of the proposed factors of the research model. The study confirmed that perceived usefulness and perceived ease are vital factors for predicting the students' behavioral intention to use social networks as learning tools. Both factors have shown a direct impact on thestudents' behavioral intention. In addition, they were act as moderators for the impact of many factors such as computer self-efficacy, perceived enjoyment and perceived mobility value on the behavioral intention.
\end{abstract}

Index Terms-University of Bahrain, social networks, TAM, perceived enjoyment, perceived mobility value.

\section{INTRODUCTION}

Social networks (SNs) have the promising to make interaction, communication, and collaboration possible and more effective and hence, SNs have been highly introduced to support and amplify educational activities [1]. SNs have been able to make a revolution in the fields of communication [2], information and knowledge sharing [3]. Such revolution has changed the way of how individuals communicate and interact with each other as well as how they access, exchange and share knowledge [4], [5]. SNs technologies discriminated by many characteristics such as the dynamic content, the ability to create and share content, collaboration, and the new ways of interaction [6]. With such features, social networks are recognized as vital tools for reshaping learning and education environment [7]. By building the existing e-learning tools based on the foundation and characteristics of the SNs, they could be more effective collaborative and interactive learning environment [8]. Such technologies have attracted the attention of the young generation [9] as well as

Recently, SNs are acknowledged as new generation of university students [10].

e-Learning platforms [11]. There is an increasing awareness of students, teachers as well as researcher on the potentials of applying SNs applications for education purpose, as a result of the growing number of the users of these applications [12], and the widely spreading of these applications among universities and educational institutes [13]. Many studies revealed that SNs have an impact on the effectiveness on the teaching and learning in general. For instant, $\mathrm{SNs}$ revealed by many research to have a potential effective on teaching and learning foreign languages as they can improve and enhance learners' oral and written language skills [14]-[16].

Many universities are offering an access to the SNs to be used as e-Learning tools to help students to access course materials, contents, and to collaborate with peers as well as with instructors. Unfortunately students do not use these online Learning facilities as they are expected to. Pituch and Lee [17] reveled that there is an absence in the utilization of these tools as a learning platform in universities. It has been witnessed that universities have not yet made the desirable efforts of utilizing these technologies [13], and SNs are still under exploration in education field [7]. Empirical research on the role of SNs in online education is limited, even thoughthe potential of SNs to contribute to educational endeavors is highlighted by researchers and practitionersand an accelerate use of social software in formal learning contextshave identified [1], [18]. In addition, the importance of social networking and it is impact on the effectiveness of learning has barely begun to be explored in the Arab countries. Therefore, finding the factors that influence the students'behavioral intention touse SNs as a learning tool in universities is perceived an important research issue. Hence, this paper sets out to investigate factors affecting the acceptance and use of SNs as learning tools at the University of Bahrain. Through an extension of the TAM, six factors that influence behavior intention to useSNsas learning tools directly and indirectly were examined. These factors include: social influence, computer self efficacy, system design and features, perceived enjoyment, previous mobility value and perceived interactivity

This paper consists of five sections; each will touch a significant component of this research. The following section will discuss the research model and hypotheses. The data collection and instruments development are discussed in section three. Section four describes the data analysis and results. Finally, the findings of this study will be discussed and a conclusion will be presented and made ready for universities and any educational institutes that intend to implement SNs as a new learning platform.

\section{RESEARCH MODEL AND HYPOTHESES}

The authors are with the IS department at the University of Bahrain, Kingdom of Bahrain (e-mail: jalammari@ uob.edu.bh).
This research study focuses on the factors that affect the 
behavioral intention to useSNs as learning tools in the Kingdom of Bahrain. To examine these factors impacting, an extended TAM model was developed as depicted in Figure (1). The model is consisted of the theory factors of perceived ease of use and perceived usefulness which have a direct effect on the behavioral intention toward accepting technology. In addition, external factors such as computer self-efficacy, system design and feature, perceived mobility value, perceived enjoyment,perceived interactivity and were set to have an indirect effect on the behavioral intention via perceived ease of use and perceived usefulness.

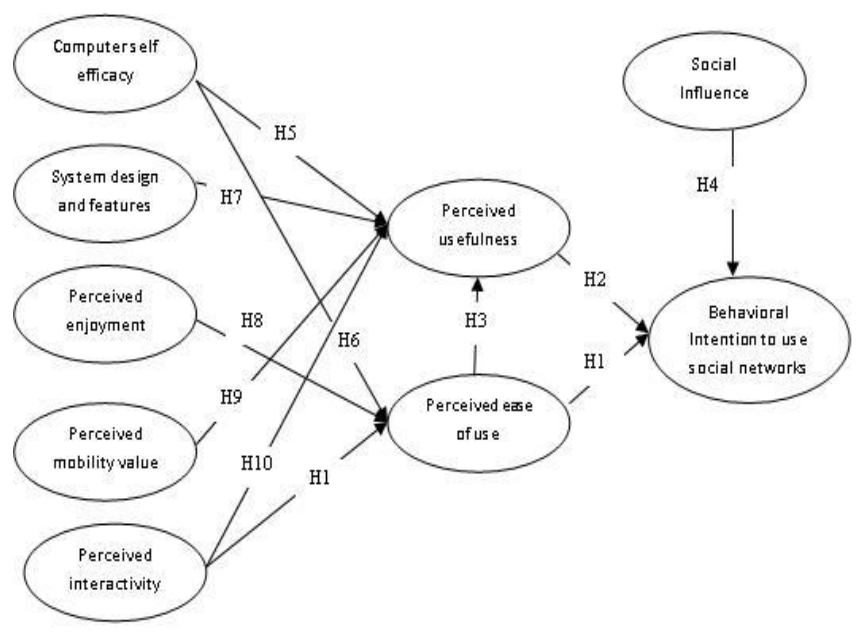

Fig. 1. Research model.

\section{A. Perceived Usefulness and Perceive Ease of Use}

Perceived usefulness and perceived ease of use have found to have a positive effect on the behavioral intention to use system [19] and that perceived ease of use was found to have a positive effect on the perceived usefulness [20]. The relationshipbetween the perceived ease of use and perceived usefulness have been revealed by a number of studies [21]. Venkatesh et al. [22] stated thatif the technology is very simple, easy to use and user-friendly itwill be perceived more usefulness. Moreover, perceived usefulness and ease of use have been found to provide a support for investigating students' acceptance to use Blackboard in higher education [23] and predicted user's acceptance and usage of may e-learning systems [24]. Although some researchers reveled that attitude toward systems use is postulated to mediate the effect of perceived ease of use and perceived usefulness on behavioral intention [25], Davis, et al, [26] suggest that perceived usefulness may have a direct impact on behavioral intention to use technology irrespective of their attitude toward this system.. Therefore the following are the suggested hypothesis:

Hypothesis 1: Perceive ease of use has a positive impact on the behavioral intention to use $\mathrm{SNs}$ as learning toolsat University of Bahrain.

Hypothesis 2: Perceive usefulnesshas a positive impact on the behavioral intention to use SNs as learning toolsat university of Bahrain.

Hypothesis 3: Perceived ease of usehas a positive impact on the perceived usefulness of SNs as learning tools at University of Bahrain.

\section{B. Social Influence}

Social influence or subjective norms has been define by
Fishbein and Ajzen [27] as "the person's perception that the most people who are important to him think he should or should not perform the behavior in question". They clarified that social influence can be considered as the perceived social pressure to engage or not to engage in a certain behavior. Although, social influence considered as a significant factor effecting behavioral intention in the early stages of experience with the new technology, this effect will be reduce over time [28]. The literature reported on many theoretical and empirical evidence regarding the importance of the role of social influence on technology use, directly or indirectly, through perceived usefulness in the workplace [29]. Social influence has been used by several researchers as critical factor in investigating the behavioral intention of using e-learning system [23], [30]. Lee [29] reported that social influence has significantly influenced perceived usefulness. However, Venkatesh and Davis [26] in their study have found a direct effect of social influence on the intentions to use information systems. Therefore, the following hypothesis was developed accordingly:

Hypothesis 4: Social influencehas a positive impact on the behavioral intention toward the use of SNs as learning toolsat University of Bahrain.

\section{Computer Self-Efficacy}

Computer self efficacy is defined as individual's self confidence in his or her ability to perform behavior and use the computer in the context of information technology usage [31]. Computer self efficacy in fact does not refer to just the straightforward computer skills. Rather, it encompasses judgments of the capability to apply those skills to broader and more complex tasks [32]. Computer self-efficacy has been indicated by many studies to have a significant effect on the behavioral intention of using e-learning system [30]. Computer self-efficacy has strong significant direct effect on the behavioral intention as well as indirect effect through users' perceived ease of use of virtual worlds for education [30], [33]. Compeau and Higgins [34]study has examined self-efficacy as a mediator between environmental variables and outcome expectations as well as actual usage. Vijayasarathy [35] found that the computer self-efficacy have a positive effect on the behavioral intention to use systems. Moreover, the individuals' confidence in their computer-related knowledge, skills and abilities can influence perception on the ease or difficulty of carrying out a specific taskand how useful that new technology will be [35]. Therefore, the following is the suggested hypothesis:

Hypothesis 5: Computer self efficacyhas a positive impact on the perceived usefulness of $\mathrm{SNs}$ as learning toolsat University of Bahrain.

Hypothesis 6: Computer self efficacyhas a positive impact on the perceived ease of use of SNs as learning toolsat University of Bahrain.

\section{System Design, Feature or Characteristics}

System design, features or characteristics are those main features of a system that can help individuals develop constructive or negative perceptions regarding the usefulness or ease of use of a system [36]. System design and feature have been added as an external factor that has an effect on perceived usefulness and perceived ease of use [37]. Several studies reported the impact of system design and features on 
ease of use and usefulness or similar constructs [38]. Al-hawari and Mouakket [39] have investigated the impact of system design features on the students' e-satisfaction and e-retention of e-learning system. They have recommended that system design and features should be taken into consideration to increase students' satisfaction and e-retention of e-learning system [40].Moreover, system characteristics and features were examined as the single external stimuli hypothesized to indirectly influence system usage through users' perceptions about the usefulness of the system. Therefore, the following hypotheses are proposed.

Hypothesis 7: System design and featureshas a positive impact on the perceived usefulness of SNs as learning toolsat University of Bahrain.

\section{E. Perceived Enjoyment}

Prior studies on technology acceptance behavior examined the effects of perceived enjoyment on perceived ease of use [42]. New technologies that are considered enjoyable are less likely to be difficult to use [42]. Perceived enjoyment is one of the factors that have been constructed in the determinants of perceived ease of use [43]. Al-hawari and Mouakket[39]have investigated how perceived enjoyment could impact students' e-satisfaction and e-retention of e-learning system. Perceived enjoyment should be taken into consideration to increase satisfaction and e-retention of e-learning system [44]. In addition, the results of Huang et al. [45] study indicate that perceived enjoyment has a positive effect on perceived ease of useand that it can predict user intentions of using M-learning. Perceived of enjoyment was the greatest predictor of users' intentions to use Second Life which is 3-D multi-user virtual environment [23]. Therefore, the following is the suggested hypothesis:

Hypothesis 8: Perceived enjoymenthas a positive impact on the perceived ease of use of SNs as learning toolsat University of Bahrain.

\section{F. Perceived Mobility Value}

Mobility guides and supports users in new learning situations and enables them to receive and transmit information anytime and anywhere via mobile devices [46]. Previous studies have indicated that the most significant feature of mobile technology is mobility. Mobile computing provides users with more freedom, as they can access information and services without having to find a physical space [47]. Mobility has three different elements including convenience, expediency and immediacy [48]. With such features, mobile users valued efficiency and availability as the main advantages of any mobile services[49]. Mobility canenhance the users' accessibility and provide them with a dynamic interaction and high levels of engagement [50]. Therefore, Anckar and D'Incau [50] consider perceived mobility value as an enabler and critical factor that can encourage users to adopt mobile technology. Redecker[4]on the other hand, stated that the availability and accessibility of SNshave a significant effect on the student's acceptance and adoption of Web 2.0 as learning tools. Therefore, this work treats perceived mobility value as a direct antecedence of perceived usefulness and so the following hypothesis is developed:

Hypothesis 9: Perceived mobility value has a positive impact on the perceived usefulness of SNs as learning toolsat

\section{University of Bahrain.}

\section{G. Perceived Interactivity}

Perceived interactivity is the degree to which an individual interconnect with a technology and perceived a belief regarding the technology's interactivity [51]. According to Song et al. [52], perceived interactivity is a combination of communication, control, and responsiveness [52]. However, based on the notion of access and control, $\mathrm{Ku}$ [53] identified six dimensions for interactivity include: immediacy of feedback, responsiveness, source diversity, communication linkages, equality of participation, and ability to terminate. With these significant combinations of features, interactivity is considered as a vital concept and the main advantage of any computer mediate communication [54]. SNs play a significant role in providing the opportunities for learners to have a social interaction in collaborative environment [55]. The interactions between students themselves and instructors, as well as between instructors themselves and students, are very important in facilitating the collaboration in the university community [4], [56]. Therefore, the following hypothesis was suggested:

Hypothesis 10: Perceived interactivityhas a positive impact on the perceived usefulness of SNs as learning toolsat University of Bahrain.

Hypothesis 11: Perceived interactivityhas a positive impact on the perceived ease of use of SNs as learning toolsat University of Bahrain.

\section{DAta COLLECTION AND ReSEARCh VARIABLES}

If Self-administered questionnaire was adopted in order to elucidate the factors influencing the students' behavioral intention toward using SNs as learning tools. The study sample is comprised of fulltime undergraduate students from the IS department at the University of Bahrain. The selected students are enrolled in the university since 2007 and onward. One hundred and eighties surveys were distributed to the students. Only one hundred and nine completed questionnaires were returned from students. The survey instrument provides a response rate of $60.6 \%$ which can be considered as high rate bearing in mind the difficulty in getting the permission from the University of Bahrain to be able to conduct the survey in the university. In addition, many students refused to answer the questionnaire either because they were very busy or they were not interested. The survey instruments for this study was developed using validated items from the prior researches. As such, scales for measuring perceived ease of use and perceived usefulness were developed by adopting items from the measurement of $\mathrm{Yu}$ et al. [57]. Scales of perceived mobility value and perceived enjoyment were developed by adopting items from the measurement of Huarg et al. [45]. Measurements of perceived interactivity and computer self efficacy were developed based on the measurements of Abbad et al. [56]. Finally, system design and features was developed by adopting items from the measurement of Alhawari et al. [39]. All items were measured on a seven-point Likert-scale anchored at both extremes to 1 (strongly disagree) and 7 (strongly agree). The midpoint (4) represents the state of unsure or "neutral". 


\section{DATA ANALYSIS AND RESUlts}

A Partial Least Squares (PLS) was applied to test the current model using Smart-PLS 2.0. PLS is a structured equation modeling method that analyzes how the items load on their constructs simultaneously with estimating all the paths in the model and is extensively used in MIS research. Data analysis in the current research possessed in two stages. First, the measurement model was evaluated to validate the reliability and validity of the constructs. Next, the structure model was estimated using hypotheses testing to test the significance of the path coefficients.

TABLE I: SELECTED CHARACTERISTIC OF THE SAMPLE

\begin{tabular}{|c|c|c|}
\hline & Frequency & $\%$ \\
\hline \multicolumn{3}{|l|}{ Gender } \\
\hline Male & 86 & $79 \%$ \\
\hline Female & 23 & $21 \%$ \\
\hline \multicolumn{3}{|l|}{ Age } \\
\hline $18-22$ & 94 & $86 \%$ \\
\hline $23-27$ & 14 & $13 \%$ \\
\hline More than 28 & 1 & $1 \%$ \\
\hline \multicolumn{3}{|c|}{ Year of study in the university } \\
\hline First year & 3 & $2.8 \%$ \\
\hline Second year & 26 & $23.9 \%$ \\
\hline Third year & 16 & $14.6 \%$ \\
\hline Fourth year or more & 64 & $58.7 \%$ \\
\hline
\end{tabular}

TABLE II: SELECTED CHARACTERISTIC OF THE SAMPLE (CONTINUE)

\begin{tabular}{|c|c|c|}
\hline & Frequency & $\%$ \\
\hline \multicolumn{3}{|l|}{ Social networking usage } \\
\hline Yes & 95 & $87 \%$ \\
\hline No & 14 & $13 \%$ \\
\hline \multicolumn{3}{|c|}{ Social networking used by students } \\
\hline $\mathrm{B} \log$ & 55 & $50 \%$ \\
\hline Facebook & 44 & $40.4 \%$ \\
\hline Wiki & 11 & $10.1 \%$ \\
\hline YouTube & 44 & $40.4 \%$ \\
\hline Others & 20 & $20.2 \%$ \\
\hline \multicolumn{3}{|c|}{ Using of Social networking per day } \\
\hline$<$ one hour & 46 & $42.2 \%$ \\
\hline $1-5$ hours & 44 & $40.4 \%$ \\
\hline $5-10$ hours & 13 & $11.9 \%$ \\
\hline More than 10 hours & 64 & $5.5 \%$ \\
\hline
\end{tabular}

Demographic characteristics of the overall participants are presented in Table I and Table II. The results in Table I revealed that most of the participants are males (79\%). This result does not represent the actual situation at University of Bahrain and especially in the IS department as the majority of the students are females. Moreover, the results show that $86 \%$ of the participants are between 18 and 22 years old and that they are senior students $(58.7 \%$ ) (are in the fourth years or more).However, freshmen (students in the first year) represents just $2.8 \%$. This result is reasonable as freshmen always reluctant to participate in any survey. They feel that they are lacking the experience and knowledge to participate in any study.

The results in Table II on the other hand, present information on the current situation regarding the usage of SNs at the IS department. The results show that most of the participants are using social networks $(87 \%)$ and specifically Blog (50\%), Facebook (40.4\%) and YouTube (40.4\%). Moreover, most of the participants are spending one to five hours per day (82.6\%) on using SNs as shown in Table II.

\section{A. Assessing the Measurement Model}

The strength of the measurement model is determined by its reliability and validity. Cronbach' alpha was used to assess the reliability value of each dimension. Reliability value of each dimension is demonstrated in Table (III). All reliability values are higher than 0.7 hence, they are considered to be in the acceptable range. Convergent validity was assessed by the examination of composite reliability and Average Variance Extracted (AVE) [58]. The data indicates that the measures are robust in term of their internal consistency reliability. The composite reliabilities of the different measures ranged from 0.721 to 0.899 which exceed the recommended threshold value of 0.7 for each construct.

\begin{tabular}{lccc}
\multicolumn{4}{c}{ TABLE III: ReliabILITY, AND CONVERGENT VALIDITY } \\
\hline Items & $\begin{array}{c}\text { Cronbach' } \\
\text { Alpha }\end{array}$ & $\begin{array}{l}\text { Composite } \\
\text { Reliability }\end{array}$ & AVE \\
\hline Behavior intention & 0.810 & 0.834 & 0.72 \\
\hline Perceived usefulness & 0.860 & 0.843 & 0.73 \\
\hline Perceived ease of use & 0.780 & 0.765 & 0.71 \\
\hline System design and features & 0.888 & 0.776 & 0.68 \\
\hline Social influence & 0.838 & 0.899 & 0.71 \\
\hline Perceived enjoyment & 0.761 & 0.744 & 0.72 \\
\hline Computer self efficacy & 0.729 & 0.721 & 0.66 \\
\hline Perceived mobility value & 0.815 & 0.865 & 0.72 \\
\hline Interactivity & 0.716 & 0.766 & 0.78 \\
\hline
\end{tabular}

Table III in addition, shows that AVE values were all above the recommended range (0.50) [59], with values ranging from 0.66 to 0.78 , thereby establishing convergent validity for each construct. Moreover, to assess the convergent validity confirmatory factor analysis with Varimax rotation was conducted to assess the underlying structure for the items of each research construct. The loading of each factor should be greater than or equal to 0.5 (the results are not shown).

\section{B. Structural Model}

The causal relationships in the proposal research model were tested. Consistent with [60], bootstrapping was applied to produce standard error and t-statistics. This permits us to measure the statistical significance of the path coefficients. The statistical objective of PLS is to show high R and significant $t$-values, thus rejecting the null hypothesis of no effect. The t-values need to be significant to support the hypothesized paths. $\mathrm{R}$ indicates the explanatory power of the latent endogenous variables. For example, Chin and Todd (1995) regards $0.67,0.33$, and 0.19 as substantial, adequate, and low values, respectively.

Properties of the causal paths, including standardized path coefficients and $t$-values are presented in Table IV. Explanation of variance for each equation in the hypothesized model is presented in Table V. As expected, hypotheses $\mathrm{H} 1, \mathrm{H} 2$ and $\mathrm{H} 4$ were all supported, in that perceived usefulness, perceived ease of use, and social influence have shown strong impact on the behavioral intention toward using $\mathrm{SNs}$ as learning tools with path coefficients and T-values of $0.351(3.211), 0.301(3.410)$, and $0.432(5.651)$ respectively. Moreover perceived ease of use has shown to has an impact on perceived usefulness $(0.250$ (2.652)). However, behavioral intention accounted for a moderate variance of perceived ease of use, perceived usefulness and social influence $(R=0.372)$. Thus only $37.2 \%$ of the variances in behavioral intention are due to these 
factors.

TABLE IV: MODEL TESTING RESULTS

\begin{tabular}{|c|c|c|}
\hline Hypothesis & $\begin{array}{c}\text { Path } \\
\text { coefficient }\end{array}$ & $T$-value \\
\hline $\begin{array}{c}\text { H1 (Perceived ease of use }-\rightarrow \text { behavioral } \\
\text { intention) }\end{array}$ & 0.351 & 3.211 \\
\hline $\begin{array}{c}\mathrm{H} 2 \text { ( Perceived usefulness - } \rightarrow \text { behavioral } \\
\text { intention ) }\end{array}$ & 0.301 & 3.410 \\
\hline $\begin{array}{c}\text { H3 ( Perceived ease of use }-\rightarrow \text { perceived } \\
\text { usefulness ) }\end{array}$ & 0.250 & 2.652 \\
\hline $\begin{array}{l}\text { H4 (Social influence }-\rightarrow \text { behavioral } \\
\text { intention) }\end{array}$ & 0.432 & 5.651 \\
\hline $\begin{array}{c}\text { H5 (Computer self efficacy }-\rightarrow \text { perceived } \\
\text { usefulness) }\end{array}$ & 0.212 & 2.43 \\
\hline $\begin{array}{c}\text { H6 ( Computer self efficacy }-\rightarrow \text { perceived } \\
\text { ease of use ) }\end{array}$ & 0.342 & 3.55 \\
\hline $\begin{array}{l}\text { H7 ( System design and features - } \rightarrow \\
\text { perceived usefulness) }\end{array}$ & 0.467 & 5.32 \\
\hline $\begin{array}{c}\text { H8 ( Perceived enjoyment }-\rightarrow \text { perceived } \\
\text { ease of use) }\end{array}$ & 0.273 & 2.56 \\
\hline $\begin{array}{l}\text { H9 ( Perceived mobility value - } \rightarrow \\
\text { perceived usefulness ) }\end{array}$ & 0.389 & 4.101 \\
\hline $\begin{array}{l}\text { H10 (Perceived interactivity }-\rightarrow \\
\text { perceived usefulness) }\end{array}$ & 0.048 & 0.871 \\
\hline $\begin{array}{c}\text { H11 ( Perceived interactivity }-\rightarrow \text { perceived } \\
\text { ease of use ) }\end{array}$ & 0.067 & 0.73 \\
\hline
\end{tabular}

Regarding the factors that indirectly influencing the behavioral intention via perceived usefulness the results show that hypotheses H5, H7 and H9 were supported. Thus, computer self efficacy, system design features and perceived mobility value have shown to has a strong impact on perceived usefulness with path coefficients and $T$-value of $0.212(2.43), 0.467(5.32)$ and $0.389(4.101)$, respectively. However, the results show that perceived interactivity $(0.048(0.871))$ has no effect on perceived usefulnessat University of Bahrain. Hence, hypothesis H10 is not supported.

TABLE V: EXPLANATION OF VARIANCE

\begin{tabular}{ll}
\hline Factor & $R$ \\
\hline Perceived ease of use & 0.203 \\
\hline Perceived usefulness & 0.245 \\
\hline Behavior intention & 0.372 \\
\hline
\end{tabular}

Furthermore, regarding the factors that indirectly influencing the behavioral intention via perceived ease of use the results show that hypotheses H6 and H8 were supported. Thus, computer self efficacy and perceived enjoyment have shown to have a strong impact on perceived ease of use with path coefficients and T-value of 0.342 (3.55) and 0.273(2.560) respectively.However, the results show that perceived interactivity has no effect on perceived ease of use (0.067(0.730))at University of Bahrain. Hence, hypothesis H11was not supported.

Moreover, the results in Table $\mathrm{V}$ demonstrate that perceived usefulness and perceived ease of use accounted for a low variance of computer self efficacy, system design and features, perceived enjoyment, perceived mobility value and perceived interactivity $R=0.245$ and $R=0.203$ respectively. Thus, less than $25 \%$ of the variances in perceived usefulness and perceived ease of use are due to examined factors.

\section{DISCUSSION AND CONCLUSION}

The aim of the current research is to investigate the factors that impact the students' behavioral intention to use SNs as learning tools at University of Bahrain. The main conclusion of the current research is that perceived usefulness and perceived ease of use are considered as the main factors in measuring the individual behavioral intention to accept and use new technology. In addition to their direct impact on the behavioral intention, they are acting as mediators for the impact of many factors such as computer self efficacy, system design and features, perceive mobility value, perceived enjoyment and perceived interactivity on the behavioral intention.

The results present that perceived ease of use and perceived usefulness have significant impact on behavioral intention. Thus, when the technology is perceived by individual as useful, simple and easy to use, then they will accept to use it. The finding is consistent with the previous studies. Dwivedi et al. [61], for instant have identified perceived ease of use and usefulness as the main factors for a successful adoption of Web 2.0 applications. In addition, Saeed et al. [23] and Venkatesh [43] studies have investigated these factors to be vital for the usage and acceptance of any new technology in the educational context. The results moreover, approved that social influence provide support for investigating students' intention to use SNs as learning tools in higher education. Social influence has been identified by previous research to have a significant effect on behavioral intention to use e-learning system [23], [30].

Computer self-efficacy on the other hand, shows to have a strong impact on both perceived ease of use and perceived usefulness [30]. Self-efficacy is considered as fundamental factor for accepting any new technology. As self-efficacy influences the individual's amount of effort and time needed to accomplish a task [62], then it will impact the decision to use and adopt a technology. In practical, when the students gain more knowledge and skills on using technology, they will be encouraged to use it. The Results of Shen and Eder [63] study have approved that self-efficacy has strong significant effect on users' perceived ease of use of virtual worlds as an education platform.

The results furthermore, revealed that system design and feature and perceived mobility value have strong impact on the perceived usefulness. Thus, system design and feature can be used to investigate students' intention to use SNs as learning tools in higher education via the perceived usefulness. The design of SNs should be clear with simple layout and user friendly features. If students perceived the SNs design and features as useful and beneficial in their informal communication and usage; they will accept to adoptthem in their formal communication as education tools [39]. Moreover, the results have approved that perceived mobility value provide a support for investigating students' intention to use SNs. Such result was also reported by Huang et al. [45] study which investigates users' behavior of mobile learning. The study has provided evidences on how important isperceived mobility value in students' behavioral intention to use SNs in term of their accessibility, flexibility, timeliness, and availability. Availability and accessibility provided by SNs tools were highlighted by Redecker [5] as important factors influencing Learning 2.0. Most of the students are preferred to access SNs via their mobile devices and laptop; therefore, they can perceive a high mobility value for SNs. 
On the other hand, the results revealed that perceived enjoyment has a strong impact on perceived ease of use, which indirectly provide a support for investigating students' intention to use SNs. If students think that SNs are enjoyable and interesting media for learning purposes, it will become very easy for them to use and adopt them in their learning process [45].

Finally, the findings of the current study revealed that the perceived interactivity can't be considered as a factor for investigate students' intention to use SNs at Kingdom of Bahrain. Perceived interactivity didn't show any impact neither on the perceived ease of use nor on perceived usefulness. The results is consistent with the findings of Abbad et al. [56] which couldn't provide an evidence on the effect of interactivity on students' behavioral intention to use e-learning system. However, perceived interaction and communication between students themselves and among teachers were highlighted by Redecker [5] as important factor influencing SNs take-up. Therefore, the important of interactivity to students' behavioral intention can't be ignored. Adopting, SNs provide students with an interactive environment with its different dimensions from communications to time. As such, this interactive environment would facilitate students' interaction with university community, help them to effectively express their ideas and knowledge and interact with students and instructors efficiently. Hence, this results need to be re-examined on a large scale sampling including students from different departments and universities from the Arab world.

University of Bahrain set a strategic planning aim to establish a fundamental change in the way teaching and learning take place as well as transferring the traditional classroom into more open and interactive environment by adopting the new technology such as SNs or WEB 2.0. This can be considered as the first step toward the educational reform in Kingdom of Bahrain. To achieve their goals, university of Bahrain needs to consider all factors influencing the student's acceptance of SNs as learning tools. In addition, there is a need to adopt new ways of re-culturing universities into an open environment and community characterized by a focus on interactive and collaborative learning.

\section{REFERENCES}

[1] C. Greenhow, B. Robelia, and J. Hughes, "Learning, teaching, and scholarship in a digital age Web 2.0 and classroom research: What path should we take now?" Educational Researcher, vol. 38, no. 4, pp. 246-259, 2009

[2] C. Espuny, J. Gonzalez, M. Lleixà, and M. Gisbert, "University Students Attitudes Towards andExpectations of the Educational Use of Social Networks. In: The Impact of Social Networks on Teaching and Learning," Revista de Universidad y Sociedaddel Conocimiento (RUSC), vol. 8, no. 1, pp. 186-199, 2011

[3] G. Grosseck, "To use or not to use web 2.0 in higher education? Procedia - Social and Behavioral Sciences," World Conference on Educational Sciences, vol. 1, no. 1, pp. 478-482, 2011.

[4] B. Schlenker. (2008). What is e-Learning 2.0?. In Learning Solutions e-Magazine. [Online]. Available: http://kelasemajazi.com/files/books/6.pdf

[5] C. Redecker, "Review of Learning 2.0 Practices: Study on the Impact of Web 2.0 Innovations on Education and Training in Europe," European Commission Joint Research Centre Institute For Prospective Technological Studies, pp. 1-121, 2009

[6] A. Harris and A. Rea, "Web 2.0 and Virtual World Technologies: A Growing Impact on IS Education," Journal of Information Systems Education, vol. 20, no. 2, pp. 137-144, 2009
[7] B. Alexander. (2008). Social Networking in Higher Education. in R. Katz, (ed.), The Tower and the Cloud, Edu. Cause. [Online]. Available: http://www.educause.edu/thetowerandthecloud/PUB7202s

[8] F. Fischer and H. Mandl, "Knowledge convergence in computer-supported collaborative learning: the role of external representation tools," Journal of the Learning Sciences, vol. 14, no. 3 , pp. 405-44, 2008

[9] S. Hamid, S. Chang, and S. Kurnia, "Identifying the Use of Online Social Networking (OSN) in Higher Education," presented at the in Same places, different spaces, Ascilite Auckland, 2009

[10] K. Brady, L. Holcomb, and B. Smith, "The use of alternative social networking sitesin higher educational settings: A case study of the e-Learning benefits of Ning in education," Journal of Interactive Online Learning, vol. 9, no. 2, pp. 151-170, 2010.

[11] S. Downes. (2005). E-Learning 2.0. Learn Magazine. [Online] Available: http://elearnmag.acm.org/featured.cfm?aid=1104968

[12] E. Eze, Making sense of Web 2.0 technology: do European students use the social media applications for educational goals?, Twente: University of Twente, 2009

[13] J. Freire. (2008). Universities and Web 2.0: Institutional challenges. E-Learning. [Online]. Available: www.elearningpapers.eu,

[14] R. Harrison and M. Thomas, "Identity in online communities: Social networking sites and language learning," International Journal of Emerging Technologies and Society, vol. 7, no. 2, pp. 109-124, 2009.

[15] M. Baralt, "The use of social networking sites for language practice and learning," Ilha do Desterro Florianopolis, pp. 277-303, 2011.

[16] L. Lomicka and G. Lord, "Introduction to social networking, collaboration, and Web 2.0 tools," in L. Lomicka and G. Lord (Eds.), The next generation: Social networking and online collaboration in foreign language learning, pp. 1-11, San Marcos, Texas: Calico, 2009.

[17] K. Pituch and Y. Lee, "The influence of system characteristics on e-learning use," Computers \& Education, vol. 47 p. 222-244, 2006

[18] A. Schroeder, S. Minocha, and C. Schneider, "The strengths, weaknesses, opportunities and threats of using social so higher and further education teaching and learning," Journal of Computer Assisted Learning, vol. 26, no. 3, pp. 159-174, 2010.

[19] W. Doll and G. Torkzadeh, "Developing a multidimensional measure of system-use in an organizational context," Information \& Management, vol. 33, no. 4, pp. 171-185, 1998.

[20] Y. Lee, Y. Hsieh, and C. Hsu, "Adding Innovation Diffusion Theory to the Technology Acceptance Model: Supporting Employees' Intentions to use E-Learning Systems," Educational Technology \& Society, vol 14, no. 4, pp. 124-137, 2011.

[21] M. Srite, "Culture as an explanation of technologyacceptance differences: an empirical investigation of Chinese an US users," Australasian Journal of Information Systems, vol. 14, no. 1, 2006.

[22] V. Venkatesh and F. Davis. (2000). A Theoretical Extension of the Technology Acceptance Model: Four Longitudinal Field Studies. Management Science. [Online]. 46. pp. 186-204. Available: http://www.jstor.org.ludwig.lub.lu.se/stable/10.2307/2634758?origin= api

[23] B. Landry, G. Rodger, and S. Hartman, "Measuring Student Perceptions of Blackboard Using the Technology Acceptance Model," Decision Sciences Journal of Innovative Education, vol. 4, no. 1, pp. 87-99, 2006

[24] N. Saeed, Y. Yang, and S. Sinnappan, "User acceptance of Second Life: An extended TAM with hedonic consumption behaviors," in Proc. the 17th European Conference on Information Systems (ECIS'09), Verona, Italy, 8-10 June 2009, pp. 2963-2975.

[25] H. Kim, "The phenomenon of blogs and theoretical model of blog use in educational contexts," Computers \&Education, vol. 51, no. 3, pp. 1342-1352, 2008

[26] F. Davis, R. Bagozzi, and P. Warshaw, "User Acceptance of Computer Technology: A Comparison of Two Theoretical Models," Management Science, vol. 35, no. 8, pp. 982-1003, 1989.

[27] M. Fishbein and I. Ajzen, Belief, attitude, intention and behavior: an introduction to theory and research, MA: Addison-Wesley, 1975.

[28] S. Ismail, “'International student acceptance on using social networking sit to support learning activities," International Journal for the Advancement of Science and Art, vol. 1, no. 2, 2010.

[29] Y. Lee, "An empirical investigation into factorsinfluencing the adoption of e-learning system," Online Information Review, vol. 30, no. 5, 2006.

[30] S. Park, "An Analysis of the Technology Acceptance Model in Understanding University Students' Behavioral Intention to Use e-Learning," Educational Technology \& Society, vol. 12, no. 3 pp. 150-162, 2009.

[31] D. Compeau and S. Huff, "Social cognitive theory andindividual reactions to computing technology: alongitudinal study," MIS Quarterly, vol. 23, no. 2, pp. 145-158, 1999. 
[32] J. Al-Ammary and S. Hamd, "Factors influencing the adoption of e-learning at University of Bahrain," in Proc. the International Arab Conference on Information Technology, ACIT'2008, Hammamet, Tunisia, December 16th, $18^{\text {th }}, 2008$.

[33] J. Shen and L. Eder, "Intentions to Use Virtual Worlds for Education," Journal of Information System Education, vol. 20, no. 2, 2009.

[34] D. Compeau, C. Higgins, and S. Huff, "Social cognitive theory and individual reactions to computing technology: a longitudinal study," MIS Quarterly, vol. 23, no. 2, pp. 145-158, 1999.

[35] L. Vijayasarathy, "Predicting consumer intentions to use on-line shopping: The case for an augmented technology acceptance model," Information and Management, vol. 41, no. 6, pp. 747-762, 2004.

[36] V. Venkatesh and H. Bala, " Technology Acceptance Model 3 and a Research Agenda on Interventions," Decision Sciences, vol. 39, no. 2, pp. 273-315, 2008.

[37] F. Davis, "User acceptance of information technology: System characteristics, user perceptions and behavioral impacts," Internat. $J$. Man-Machine Stud, vol. 38, no. 3, pp. 475-487, 1993.

[38] G. Dickson, G. DeSanctis, and D. McBride, "Understanding the Effectiveness of Computer Graphics for Decision Support: A Cumulative Experimental Approach," Communications of the ACM, vol. 29 , pp. 40-47, 1986

[39] M. Al-Hawari and S. Mouakket, "The influence of technology acceptance model (TAM) factors on students' e-satisfaction and e-retention within the context of UAE e-learning. Education," Business and Society: Contemporary Middle Eastern Issues, vol. 3, no. 4, pp. 299-314, 2010

[40] S. Al-Gahtani, "System characteristics, user perceptions and attitude in the perception of information technology acceptance: a structural equation model," in Proc. Diffusion Interest Group in Information Technology, Helsinki, Finland, Dec. 12, 1998.

[41] M. Yi and Y. Hwang, "Predicting the use of web-based information systems: self-efficacy, enjoyment, learning goal orientation, and the technology acceptance model," Int. J. Human-Computer Studies, vol. 59, pp. 431-449, 2003.

[42] M. Alley and M. Gardiner, "Application and device characteristics as drivers for smart mobile device adoption and productivity," International of Organizational Behavior, vol. 17, no. 4, 2012.

[43] V. Venkatesh, "Determinants of perceived Ease of Use: Integrating Control, Intrinsic Motivation, and Emotion into the Technology Acceptance Model," Information Systems Research, vol. 11, no. 4, pp. 342-365, 2000.

[44] D. Wu, S. Hiltz, and M.Bieber, "Acceptance of educational technology: Field Studies of asynchronous participatory examinations," Communications of the Association for Information Systems, vol. 26 , no. 1, pp. 451-476, 2010

[45] J. Huang, Y. Lin, and S. Chuang, "Elucidating user behaviour of mobile learning: A perspective of the extended technology acceptance model," The Electronic Library Emerald Group Publishing Limited, vol. 25 , no. 5, pp. 586-599, 2007.

[46] N. Sukiand and N. Suki, "Use behavior towards ubiquitous M-learning," Turkish Online Jornal of Distance Education- TOJDE, vol. 12, no. 3, Article 5, 2011.

[47] P. May, Mobile Commerce: Opportunities, Applications, and Technologies of Wireless Business, Cambridge University Press, 2011.

[48] P. Seppälä and H. Alamäki, "Mobile learning in teacher training," Journal of Computer Assisted Learning, vol. 19, no. 3, pp. 330-335, 2003.

[49] T. Hill and M. Roldan, "Toward third generation threaded discussions for mobile learning: opportunities and challenges for ubiquitous collaborative environments," Information Systems Frontiers, vol. 7, no. 1, pp. 55-70, 2005

[50] B. Anckar, and D. D'Incau, "Value creation in Mobile Commerce: findings from a consumer survey," Journal of Information Technology Theory \& Application, vol. 4, no. 1, 2002.

[51] B. Shipp and B. Phillips, "Perception of social networks' usability impact of perceived interactivity and technology acceptance," Issue in Information Systems, vol. X1, no. 1, 2010.

[52] J. Song and G. Zinkhan, "Determinants of Perceived Web Site Interactivity," Journal of Marketing, vol. 72, pp. 99, 2008.

[53] $\mathrm{L}$. Ku, "Impacts of Interactivity from Computer-Mediated Communication in an Organization Setting: A Study of Electronic Mail," Doctoral Dissertation, Michigan State University, 1992.

[54] L. Zhao and Y. Lu, "Perceived interactivity: exploring factors affecting micro blogging service satisfaction and continence intention," Decision Support Systems, vol. 53, no. 4, 2012.

[55] C. Chai, H. Woo, and Q. Wang, "Designing Web 2.0 basedconstructivist-oriented e-learning units," The Electronic Library Emerald Group Publishing Limited, vol. 27, no. 2, pp. 68-78, 2010.

[56] M. Abbad, D. Morris, and C.Nahlik, "Looking under the Bonnet: Factors Affecting Student Adoption of E-Learning Systems in Jordan," International Review of Research in Open and Distance Learning, vol. 10, no. 2, 2009.

[57] A. Yu, S. Tian, D. Vogel, and R. Kwok, "Can learning be virtually boosted? An investigation of online social networking impacts," Computers \& Education, vol. 55, no. 4, pp. 1494-1503, 2010.

[58] C. Fornell and D. Larcker, "Evaluating structural equation models with unobservablevariables and measurement error," Journal of Marketing Research, vol. 18, no. 1, 39-50, 1981

[59] J. Hair, R. Anderson, R. Tathan, and W. Black, Multivariate data analysis with reading, Englewood Cliffs, NJ: Prentice Hall, 1998.

[60] C. Chin and P. Todd, "On the use, usefulness and ease of use of structural equation modeling in MIS research: a note of caution," MIS quarterly, vol. 19, no. 2, 1995.

[61] Y. Dwivedi, M. Williams, B. Ramdani, S. Niranjan, and V. Weerakkody. (2011). Understanding Factors For Successful Adoption Of Web 2.0 Applications. [Online]. Available: http://csrc.lse.ac.uk/asp/aspecis/20110261.pdf

[62] O. Khorrami-Arani, "Researching computer self-efficacy," International Education Journal, vol. 2, no. 4, pp. 17-25, 2011.

[63] J. Shen and L. Eder, "Intentions to Use Virtual Worlds for Education," Journal of Information System Education, vol. 20, no. 2, pp. 225-233, 2009.

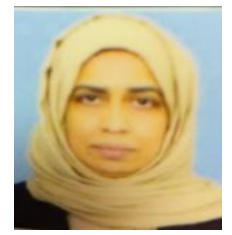

Jaflah Hassan Al-Ammary is the head of the Department of Information Systems in the College of IT at University of Bahrain. She holds PhD from University of Murdoch (Australia). Al-Ammary's research interest focuses on Strategic alignment, Knowledge Management and Information technology and education.

Al-Ammary has many publications on KM-strategic alignment and the strategic role of the Information systems and SISP at organizations of Bahrain. On the other hand, she has conducted number of researches to examine the importance of the educational technology (such as blackboard and Online Collaboration Learning) on enhancing the learning and teaching process and the emergent roles of professional learning community in developing the teachers' teaching capabilities and responsibility toward students in the secondary school of the Kingdom of Bahrain. Most of these researches have been published in international conferences and journals. 